UDC 801.82:821

DOI https://doi.org/10.32838/2710-4656/2021.3-1/19

Gryshkova R. O.

Petro Mohyla Black Sea National University

\title{
STYLISTIC ANALYSIS OF JOE BIDEN'S INAUGURATION SPEECH
}

An attempt to study President Joe Biden's inauguration speech from the view points of style, general impression, philological aspects, public importance has been made in the article. The inauguration speech is considered here as an example of a political discourse which contains all its features: expressiveness, briefness, persuasion, repetition of some words and parts of the sentence, figurativeness. Political discourse and its peculiarities is characterized. This research is conducted in order to investigate the persuasive stylistic devices employed by Joe Biden in his inauguration speech. The speech is regarded as an act of communication and statements, requests, promises and apologies are examples of the four major categories of communicative illocutionary acts: constatives, directives, commissives and acknowledgments. Descriptors of each category are given and the type of Joe Biden's inauguration speech is defined. It is an example of a constative type of speech act with such its characteristics as affirming, announcing, answering, attributing, claiming, classifying, concurring, confirming, denying, disagreeing, disclosing, disputing, identifying, informing, insisting, predicting, ranking, reporting, stating.

Most attention is paid to the stylistic peculiarities of the speech that allowed the President to influence the target audience. Word composition, vocabulary, structure, oratory methods used by the American president are researched in the article. The main ideas of the speech-democracy and unity - and the ways the president is going to realize them are defined. The most important personal characteristics which helped him gain the highest position in the country are cleared out.

All conclusions are made as the result of the stylistic analysis of the text and are confirmed by the quotations from the speech.

Key words: political discourse, inauguration speech, peculiarities, stylistic devices, vocabulary, characteristic.

Introduction. American President's inauguration speech is generally considered as the strategy of the country's development and the program of actions for the nearest four years. The forty sixth American president Joe Biden's inauguration speech is not an exception. In the address to the nation and the world community his professional speechwriters tried to reflect all his ideas concerning the most important questions of American life and the international situation. As a rule, all presidents promise to make America stronger and the life of the people better and happier. But Joe Biden appeared in the more tensed situation than his predecessors because of the corona virus that spread all over the world and made a lot of harm to Americans carrying away thousands of people and leaving hundreds of unemployed. That is why American society was expecting their new president to define the steps directed to bettering the situation in the labor market, combating the corona virus, uniting the nation and supporting democracy.

In the article Joe Biden's inauguration speech is considered as a political and social discourse aimed at comprehension by all American citizens no matter they supported him or his competitor. So we are going to characterize the speech as an example of a political and social discourse the distinguishing features of which are: expressiveness, briefness, persuasion, repetition of some words and parts of the sentence, figurativeness.

Analysis of relevant researches. According to I. Galperin, publicistic style became discernible as a separate style in the middle of the $18^{\text {th }}$ century. Unlike other styles, the publicistic style has spoken varieties, in particular, the oratorical substyle. In this style "the most powerful instrument of persuasion is brought into play: the human voice" [10, p. 296]. Academician A. Potebnya wrote: "Oratorical speech aims not only at the understanding and digesting of the idea, but also serves simultaneously as a spring setting off a mood (which is the aim) that may lead to action" [5, p. 17]. In the course of time when the notion of "discourse" rooted in philology the term "publicistic style" was replaced by more modern term "political discourse" which supposes taking into consideration the target audience, the time and circumstances of the utterance, the speaker's personality etc. Certain typical features of the spoken variety of speech present in political discourse are: direct address to the audience, the use of the $2^{\text {nd }}$ per- 
son pronoun you, sometimes contractions and the use of colloquial words. Besides it contains many obligatory characteristics of political discourse: evaluation, appealing, passion, emotions, figurativeness, simplicity and accessibility.

Now political discourse is being researched by numerous scientists, as it is constantly changing according to the changes in home and foreign policies of different countries and constantly changing international situation. It is the political discourse where neologisms and nonce-words most often occur, and traditional words may possess unusual meanings. In Ukraine it was researched by O. Aleksievets [1], T. Vashchuk [2], I. Koroliov [3], I. Petrenko [4] and others. In English-speaking countries scientific works by Bobin, Charteris-Black, Chilton, Woods, Vesnic-Alujevic and some others are devoted to researching political discourse. As a rule politicians study inauguration speech of all presidents very attentively comparing them with the speeches of their predecessors, and linguists interpret their inner sense and potential influence on the target audience.

Politicians try to convince people to change their views using persuasive strategies in their political speeches. Politics is seen as a struggle for power (Chilton, 2004) and in this struggle politicians want to present their plans and policies by providing evidence, persuading the electorate to act in their favor, and convincing them to support their plans and thoughts. Stylistic manipulation is typical of political discourse, and politicians have learned well to obtain power through "the oratorical art of manipulating language for persuasive ends" [11].

Actually politicians manipulate and frame their ideas and messages in order to better reach their electorates (Bobin, 1988). Attracting the audience's attention to the most important ideas, it has to do with the intention, act and effect of changing an audience's thinking (Charteris-Black, 2011).

Before analyzing the president's inauguration speech in details it is necessary to define the type of speech it belongs to. Messages incorporated in political discourse aim at persuading the audience and affecting their attitudes and beliefs (VesnicAlujevic, 2011). According to Vesnic-Alujevic, persuasion has four interdependent elements including: the speaker, the audience, the message and the way the message is conveyed. In the case with Joe Biden none of these four elements of persuasion has been researched so far.

The aim of the study is:

- to characterize the political discourse to which the inauguration speech belongs;
- to define stylistic devices which help clear out some Joe Biden's personal characteristics that allowed him to be elected president and gain the highest position in the country (the speaker);

- to describe stylistic devices which are used in the speech to characterize the American people as it is comprehended by the president (the audience);

- to underline the stylistic specifics used to express the main ideas of the speech and the ways the president is going to realize them (the message);

- to analyze Joe Biden's inauguration speech from the viewpoint of its stylistic peculiarities as the strategy of the country's development and the program of actions for the nearest four years (the way the message is conveyed).

Research findings. Speech acts are acts of communication. To communicate is to express a certain attitude, and the type of speech act being presented corresponds to the type of attitude being expressed. As an act of communication, a speech act succeeds if the target audience identifies, in accordance with the speaker's intention, the attitude being demonstrated. In saying something a person generally intends more than just to communicate - getting oneself understood is intended to produce some influence on the listener. According to the nomenclature used by Kent Bach and Michael Harnish [7] who develop a detailed taxonomy in which each type of illocutionary act is individuated by the type of attitude expressed. Statements, requests, promises and apologies are examples of the four major categories of communicative illocutionary acts: constatives, directives, commissives and acknowledgments. Kent Bach and Michael Harnish give descriptors of each type:

- constatives: affirming, alleging, announcing, answering, attributing, claiming, classifying, concurring, confirming, conjecturing, denying, disagreeing, disclosing, disputing, identifying, informing, insisting, predicting, ranking, reporting, stating, stipulating;

- Directives: advising, admonishing, asking, begging, dismissing, excusing, forbidding, instructing, ordering, permitting, requesting, requiring, suggesting, urging, warning;

- Commissives: agreeing, guaranteeing, inviting, offering, promising, swearing, volunteering;

- Acknowledgments: apologizing, condoling, congratulating, greeting, thanking, accepting (acknowledging an acknowledgment) [7].

Joe Biden's inauguration speech is an example of a constative type of speech act with such its characteristics as affirming, announcing, answering, attributing, claiming, classifying, concurring, con- 
firming, denying, disagreeing, disclosing, disputing, identifying, informing, insisting, predicting, ranking, reporting, stating.

After defining the type of speech it is necessary to state its composition, i.e. the number of sense parts and micro subjects of these parts.

Joe Biden's inauguration speech begins with stating This is America's day. This is democracy's day. A Day of history and hope. Of renewal and resolve.

The main body of the speech consists of several parts in which Joe Biden expresses his desire to support the course of democracy and thanks his predecessors of both parties for their presence here. Having mentioned the violence sought to shake this Capitol's very foundation he stresses on the necessity of carrying out the peaceful transfer of power and states we have much to do.

Saying "my whole soul is in this: bringing America together. Uniting our people. And uniting our nation" Biden announces the motto of his work for the benefit of the people. "I will be a president for all Americans. I will fight as hard for those who did not support me as for those who did". These sentences characterize Joe Biden as the speaker who believes in his people, understands the situation with those who did not support him and is ready to unite the country. His decisiveness and confidence in his ability to reach his goals demonstrate his willpower, readiness to serve his people, positive thinking and success orientation. These personal features as well as his consecutiveness, political perspicacity, strong desire to better the life of Americans, readiness to struggle for democracy and unity of the nation helped him to be elected president and gain the highest position in the country.

Characterizing the current situation in the country Joe Biden says:

Few periods in our nation's history have been more challenging or difficult than the one we're in now. A once-in-a-century virus silently stalks the country. It's taken as many lives in one year as America lost in all the World War II. Millions of jobs have been lost. Hundreds of thousands of businesses closed. The dream of justice for all will be deferred no longer. A cry for survival comes from the planet itself. A cry that can't be any more desperate or any more clear. And now, a rise in political extremism, white supremacy, domestic terrorism that we must confront and we will defeat.

To overcome these challenges - to restore the soul and to secure the future of America - requires more than words. It requires that most elusive of things in a democracy: Unity.

Being a deeply religious person Joe Biden cites St Augustine, a saint of his church, who many centu- ries ago wrote that "a people was a multitude defined by the common objects of their love". And he states that the common objects they love are opportunity, security, liberty, dignity, respect, honor, and the truth. Remembering that most Americans are religious people and trust in God president Biden mentioned the Bible in his speech. Referring to it he says "we come together as one nation, under God, indivisible ..." And continues:"I promise you this: as the Bible says, weeping may endure for a night but joy cometh in the morning". He calls his citizens: "Let us say a silent prayer for those who lost their lives, for those they left behind, and for our country. Amen." Joe Biden ends his speech with the words: "May God bless America and may God protect our troops. Thank you, America."

Addressing his audience, "my fellow Americans", Joe Biden calls it "a great nation and a good people". Identifying himself as one of the Americans he uses the word "we" eighty two times, and only twenty five times the pronoun " $P$ " is used. It shows the president is more concentrated on the people than on his personality.

The main ideas of the speech and the ways the president is going to realize them are expressed by the repetition of the words "Unity" and "democracy" which are used relatively nine and ten times. Joe Biden says:

"This is our historic moment of crisis and challenge, and unity is the path forward. And we must meet this moment as the United States of America. If we do that, I guarantee you, we will not fail. We have never, ever, ever failed in America when we have acted together."

Characterizing the tensed situation in the country, the president states:

"This is a time of testing. We face an attack on democracy and on truth. A raging virus. Growing inequity. The sting of systemic racism. A climate in crisis. America's role in the world. But the fact is we face them all at once, presenting this nation with the gravest of responsibilities."

Drawing attention to the problems America faces just now Joe Biden uses not homogeneous parts but short nominative sentences to make the speech more emotional and convincing. It is justified stylistically as it influences the audience's comprehension of the current situation in the country. As the human voice is one of the crucial elements of any aural speech the president deliberately uses short abrupt sentences to make the listeners understand how complicated the situation in the country is. 
Understanding that his speech is addressed to be heard by the audience and not to be read the president uses very short sentences with numerous repetitions saying: "We have much to do in this winter of peril and possibility. Much to repair. Much to restore. Much to heal. Much to build. And much to gain".

Calling people to unite to fight the common foes they face: "anger, resentment, hatred. Extremism, lawlessness, violence. Disease, joblessness, hopelessness" the president states: "With unity we can do great things. We can right wrongs. We can put people to work in good jobs. We can teach our children in safe schools. We can overcome this deadly virus. We can deliver racial justice. We can make America, once again, the leading force for good in the world".

Having mentioned tragic moments in American history - the civil war, the Great Depression, world war, 9/11, - the president states:"...enough of us came together to carry all of us forward. And we can do so now. We can see each other not as adversaries but as neighbors. We can treat each other with dignity and respect. We can join forces..." The modal verb can is used to demonstrate the president's confidence in the ability of the Americans to overcome these troubles. Moreover all these sentences start with the word "we" showing that the president trusts in his people and is sure to reach his goals together with Americans.

Now according to the algorithm of a stylistic analysis it is necessary to define the character of sentences connection in Joe Biden's inauguration speech and to clear out whether it is parallel or chainable. The very first look at the text proves that the character of sentences connection is parallel. There are no connecting words like that is why, as a result, so, therefore or any other words demonstrating the reason-consequence unities in the text. Connection of the sentences in the inauguration speech is done by means of its logical and emotional aspects as it was first of all intended for listening comprehension.

Being an example of a political discourse the inauguration speech contains social and political vocabulary (democracy, unity, the peaceful transfer of power, political extremism, domestic terrorism, historic moment of crisis and challenge, violence, conservative $v$ liberal, peace, progress and security), gradations (...more than two centuries, over the centuries, 108 years ago, yesterday, today, tomorrow), using verbs which mean a repeating action (rebuild, renewal, resolve, retreat, restore,), other devices of emotional influence.

Numerous appealing to the listeners with the words "we, my friends, we come together as one nation, we are a good people, my fellow Americans etc." and calls for the people: “... let us start afresh. Let us listen to one another. Hear one another. See one another. Show respect to one another" illustrates the invocatory character of his speech, the device which makes any aural speech very emotional and provokes listeners to trust every word in it.

Using the rhetorical questions "Will we rise to the occasion? Will we master this rare and difficult hour? Will we meet our obligations and pass along a new and better world for our children?" to attract the audience's attention the president answers:" I believe we must and I believe we will. We will write the next chapter in the American story" demonstrating his firm confidence in his ability to do this together with his people. Asking general questions with a rising tone is a rather successful stylistic device as modulation of a human voice allows to influence the audience's consciousness.

Analyzing Joe Biden's inauguration speech from the viewpoint of the way the message is conveyed to express its emotional influence on the audience such stylistic devices as epithets and metaphors are used. Epithets deadly virus, safe schools, harsh, ugly reality, a desperate cry, eternal peace, a painful lesson, cascading crises (to name a few) help to make his speech brighter and more impressive, they demonstrate the president's attitude towards his people and the situation in the country. Metaphors "if we're willing to stand in the other person's shoes", "...this winter of peril and possibilities", "A cry for survival comes from the planet itself" help to make the speech bright, appealing and full of sense. The message is conveyed by means of short abrupt sentences, direct addressing the people, numerous repetitions, appeals and calls and with the usage of the main instrument of any oral speech - human voice.

Conclusions. Detailed stylistic analysis of Joe Biden's inauguration speech as an example of a political discourse shows that numerous stylistic devices (short abrupt sentences, repetitions, appeals and calls, gradations, epithets, metaphors) are used to persuade people to trust him. Political discourse to which the inauguration speech belongs is characterized by expressiveness, briefness, persuasion, repetition of some words and parts of the sentence, figurativeness. Messages incorporated in political discourse aim at persuading the audience and affecting their attitudes and beliefs. Direct address to the audience, the use of the $2^{\text {nd }}$ person pronoun you, sometimes contractions and the use of colloquial words are also typical for political discourse.

Stylistically Joe Biden's personal characteristics that allowed him to be elected president and gain the highest position in the country are expressed by means of selection the accurate vocabulary that cor- 
responds to the message conveyed, personification in addressing the people with the words "my fellow Americans", "my whole soul is in this: bringing America together. Uniting our people. And uniting America". He calls the people: "Let us add our own work and prayers to the unfolding story of our nation." God, St. Augustine and the Bible are mentioned in the speech which justifies Joe Biden's deep religious beliefs.

Remembering that most Americans are religious people and trust in God, president Biden mentioned the Bible in his speech. Political aspects of his speech demonstrate his readiness to pursue the policy of non-violent solving problems and keeping principles of democracy defined by the founding fathers of the nation. So Joe Biden's inauguration speech being so rich and bright, emotional and appealing thanks to its vocabulary, structure, stylistic devices persuaded his people to believe that all together they will reach democracy and unity in the country.

All president's beliefs, plans and priorities are reflected in his speech.

\section{References:}

1. Алексієвець О. Історія та сучасність політичної лінгвістики. Україна - Свропа - Світ : міжнародний збірник наукових праць. Тернопіль : ТНПУ, 2012. Вип. 9. С. 248-255.

2. Ващук Т. Політичний дискурс як об'єкт лінгвістичного дослідження. Вісник Житомирського державного університету ім. Івана Франка. 2007. № 33. С. 182-185.

3. Корольов І.Р. Поняття дискурсу в сучасному мовознавстві: визначення, структура, типологія. Studia Linguistica: 3б. наук. праць КНУ ім. Тараса Шевченка. Київ : Видавничо-поліграфічний центр «Київський університет», 2012. Вип. 6. С. 285-305.

4. Петренко І.І. Політичний дискурс: зміст, особливості, функції. Вісник Київського національного університету імені Тараса Шевченка. Філософія. Політологія. Київ, 2010. № 100. С. 54-57.

5. Потебня А.А. Проблемы лингвистической стилистики. Москва, МГПИИЯ, 1969.

6. Bach, Kent (1994). 'Conversational impliciture', Mind \& Language 9: 124-162.

7. Bach, Kent, Robert M. Harnish (1979), Linguistic Commuication and Speech Acts, Cambridge, Mass.: MIT Press.

8. Joe Biden's inauguration speech. https://www.politico.com/news/2021/01/20/joe-biden-inaugurationspeech-transcript-full-text-460813.

9. Searle, John R. (1970). Speech Acts: An Essay in the Philosophy of Language, Cambridge, Eng.: Cambridge University Press.

10. Galperin I.R. Stylistics. M., Higher School Publishing House, 1971.

11. Searle, John R. (1970). Speech Acts: An Essay in the Philosophy of Language, Cambridge, Eng.: Cambridge University Press.

\section{Гришкова Р. О. СТИЛІСТИЧНИЙ АНАЛІЗ ІНАВГУРАЦІЙНОЇ ПРОМОВИ ДЖОЗЕФА БАЙДЕНА}

Статтю присвячено стилістичному аналізу інавгурачійної промови президента Сполучених Штатів Америки Джозефа Байдена. Промова досліджується з точки зору стилю, загального враження, філологічних аспектів, суспільної значущості. Інавгураиійна промова розглядається як приклад політичного дискурсу, щео містить такі характеристики: експресивність, адресність, стислість, переконливість, повтор окремих слів і частин речень, фігуративність. Політичному дискурсу в його усній та письмовій формах притаманна наявність різноманітних стилістичних засобів і фігур мови. Дослідження спрямоване на виявлення переконливої сили стилістичних засобів, використаних Джо Байденом у його інавгураиійній промові. Розцінюючи промову як акт комунікації, зазначається, щзо твердження, запит, обіиянки і вибачення є прикладами чотирьох основних категорій комунікативного акту: констатачії, доручення, наказу, визнання. Надано дескриптори кожної категорії, визначено тип інавгураційної промови як констатувальний. Цей тип характеризується ствердженням, оголоменням, відповіддю, зверненням, визначенням, домаганням, зазіханням, класифікачією, погодженням, підтвердженням, запереченням, незгодою, визнанням, наполяганням, передбаченням, ранжуванням тощо.

Значна увага приділена стилістичним особливостям промови, що дозволили президентові вплинути на иільову аудиторію. У роботі досліджені словотвір, структура речень, політична й сочіальна лексика, ораторські прийоми, використані президентом у промові. Визначено основні ідеї промови, як-от єдність і демократія, та шляхи їх упровадження в життя суспільства. Виявлено найважливіші риси особистості президента, що дозволили йому обійняти найвищу посаду в державі.

$У_{c i}$ висновки зроблено на основі стилістичного аналізу інавгурачійної промови і підтверджено цитатами з тексту.

Ключові слова: політичний дискурс, інавгурачійна промова, стилістичні засоби, особливості, словниковий запас, характеристика. 